\title{
HOW TO MAKE ISLAMIC LAW AS THE STATE LEGAL POLICY OF INDONESIA: Constitutional and Sociological Arguments
}

\author{
Abu Hapsin \\ Universitas Islam Negeri Walisongo, Semarang \\ e-mail:abu_hapsin@walisongo.ac.id
}

\begin{abstract}
This article aims to answer some questions: what is the meaning of "equal right" and "religious freedom" written in the text of UUD 45? How if, in the name of religious freedom, other people's rights are offended? how if, in implementing Islamic law, others people's rights are offended? Indonesian Constitution (UUD 45) gives freedom to every follower of a given religion to concretize his religious convictions in public life provided that, in doing so, the fundamental right of others are not offended. The UUD 45 also gives freedom to every citizen to make his religious convictions or religious teachings become a state legal policy as long as he or she follows the procedural constitution written in the UUD 45. However, after becoming state legal policy, Islamic law can no longer be claimed "Islamic Law", because it's now provided for answering the partial question of life, namely how to administer the state. From a sociological point of view, in order that the process of legislation runs smoothly, Islamic Law should first be transformed into living norms. Hence, it will be easier for the society to abide the law which originated from living norms. Since the function of law in maintaining public peace and order depends, for its effectiveness, on the actual social norms of the community, social acceptance is of great importance. Two ways of resolution will be discussed in this article, these are democratic resolution and transforming Islamic Law into social norms.
\end{abstract}

\section{[1]}

Artikel ini bertujuan untukmenjawab beberapa pertanyaan, apa arti "hak yang sama" dan "kebebasan beragama" yang tertulis dalam teks UUD 45? Bagaimana jika atas nama kebebasan beragama bersinggungan dengan hak orang lain? Bagaimana pula jika dalam menerapkan hukum Islam mengganggu ataupun mengabaikan hak orang lain? UUD 1945 memberikan kebebasan kepada setiap penganut agama untuk mengekspresikan keyakinan agamanya dalam kehidupan publik dengan cacatan tidak mengganggu dan mengabaikan hak orang lain. UUD 1945 juga memberikan kebebasan kepada setiap warga negara untuk membuat keyakinan agama atau ajaran agamanya menjadi kebijakan hukum negara selama tetap mengikuti prosedur yang tertulis dalam UUD 1945. Namun, setelah menjadi kebijakan hukum negara, hukum Islam tidak dapat lagi diklaim sebagai "Hukum Islam", karena hukum tersebut telah dibuat dalam rangka memberikan solusi terhadap berbagai macam permasalahan dalam kehidupan, lebih tepatnya hukum tersebut telah menjadi pengatur sebuah Negara. Dari sudut pandang sosiologis, agar proses perundang-undangan berjalan lancar, Hukum Islam pertama-tama harus diubah menjadi norma hidup sehingga akan lebih mudah bagi masyarakat untuk mematuhi hukum yang berawal dari norma hidup. Karenanya hukum berfungsi dalam menjaga ketertiban publik, dan ini bergantung pada norma sosial yang berlaku pada masyarakat, sehingga akan mudah diterima oleh masyarakat. Dua tawaran solusi akan dibahas dalam artikel ini, yaitu: resolusi demokratis dan mengubah Hukum Islam menjadi norma sosial.

Keywords: Islamic law; living norms; UUD 45; equal right 
Abu Hapsin

\section{Introduction}

Indonesia is neither secular nor a theocratic state. Yet it is, by no means, a secular state for religious life is not totally separated from the state. Although Islam constitutes the religion of the majority, every citizen, regardless of his/her religious background has the same right to hold any governmental position, including the fundamental ones, the presidential position, the head of the People's Consultative Body, the head of the House of Representative and the like. Article 27, verse (1) of the 1945 Indonesian Constitution (UUD 1945) clearly states that "Without any exception, all citizens shall have an equal position in Law and Government and shall be obliged to uphold that Law and Government".

The above article indicates that the Indonesian Constitution (UUD 45) does not give any special treatment to a given religion to be a state religion. Yet, the UUD 45 gives freedom to every citizen to adhere to his/her own religious convictions. Every religious follower is free, not only to hold his own religious convictions but also to express those convictions in daily life. This guarantee is stated explicitly in the UUD 45 article 29, verse 2: "The state shall guarantee freedom to every resident to adhere to his respective religion and faith and to perform his religious duties in conformity with that religion and that faith".

From the above feature, it can be understood that, on one hand, the UUD 45 gives equal rights to every citizen to hold any governmental position and treats all citizens equally before the law. On the other hand, it provides the right to religious freedom to everyone, not only citizens but to all residents who live in Indonesia. At a glance, these two articles look in harmony and are mutually complementary. But if we look deeper, there is a hidden potentiality to clash with each other. The problem is what is the meaning of "equal right" and "religious freedom" written in the text of UUD 45? How if, in the name of religious freedom, other people's rights are offended? For instance, the Muslims in Indonesia might say that attempting to make Islam into a state Ideology, as well as attempting to make Islamic Law to be the state legal policy, are normal in democratic discourse. But the problem then arises, how if, in implementing Islamic law, others people's rights are offended? Failure to answer this problem is bound to lead to political as well as constitutional chaos. To answer these problems, two ways of resolution will be discussed in 
this article, these are democratic resolution and transforming Islamic Law into social norms.

\section{Implementing Religious Teaching in a Democratic Constitution}

The guarantee provided by UUD 45 is not only the right to manifest religious teaching such as Islamic Law as an individual right, but following the logic of a democratic constitution, it (UUD 45) also guarantees the right of every religious follower to attempt to make his/her religious tradition to become the state policy. Thus, insofar as Islamic Law is not contradictory to other fundamental rights which are guaranteed by UUD 45, it can be adapted to become national legal policy. And the same would be true for other religious groups. Its position is the same as the position of customary laws. It is a legitimate source of national legal policy. But, since Indonesia follows the principle of democracy, the problem here is what is a constitutionally justifiable way to apply the Islamic Law to the positive law of Indonesia? In other words, can Islamic Law, through a democratic process, be applied to the Indonesian system of law? This is another problem that needs further explanation by using a democratic resolution theory.

Democratic resolution in relation to religious freedom entails the involvement of all religious adherents in the process of making decisions. All citizens, without regard to their religious background, have the right to express their ideas and to participate in the political arena. Even though the majority frequently becomes a determinant factor in the process of decision-making, the rights of the minority groups cannot be eliminated by that decision. In brief, democracy is not the same as the dictatorship of the majority. ${ }^{1}$

All countries that follow the principle of democracy are bound to deal with what Prof. Gamwell ${ }^{2}$ calls the "modern political problematic". The modern political problematic refers to a condition in which a religious authority loses its domination over the state. At the same time, there is an increasing freedom to choose a given religion can possibly be done only by force. A limitation by

\footnotetext{
${ }^{1}$ Alexander Peczenik, On Law and Reason (Dordrecht: Springer Science and Business Media, 1989), p. 39.

${ }^{2}$ Franklin I. Gamwell, The Meaning of Religious Freedom, Modern Politic and The Democratic Resolution (Albany: State University of New York Press, 1995), p. 5.
} 
force, however, is not a good resolution since it is not consistent with the idea of democracy.

A democratic resolution to the modern political can only be worked out by letting the society or political community exercise their "activities". Prof. Gamwell $^{3}$ thinks that human activities are distinguished by the question which is "explicitly" asked. Thus, religious activities can be differentiated from political activities because of the "implicit" question. Based on this account, he defines religion as "the primary form of culture in terms of which the comprehensive question is explicitly asked and answered". The term "form of culture" here means that a religion is "a set of or system of concepts or symbols in terms of which human beings explicitly understand themselves", while the term "comprehensive" means the purpose of life 4 . Thus, the question about religious activities can be formulated: what should the activities of religion be or what should the religion do to fulfill the purpose of life?

While religion asks and answers "explicitly" the comprehensive question, politics asks and answers "explicitly" the question about the state. Therefore political activity might be formulated "what should the activities of the state be and what should the state do?"5

To clarify the above feature, let us look at the following example. If a state implements the law of monogamy, it means "implicitly" that it is implementing Christian teaching. Since it has become a state policy, the implementation of the monogamous principle is not intended to answer the "comprehensive question", that is the question as to what should a state do to administer the country in dealing with the question of marriage law. The Christian community might say that a state is implementing Christian religious teaching, but the state cannot explicitly claim that it is implementing the Christian teaching, even though it might be "implicitly" implementing the Christian religious teaching.

A human being, in his authentic meaning, can only be found if he is freed to determine it himself by letting him adhere to his religious conviction or religious teaching. This is the logic of the common claim that religion provides

\footnotetext{
3Ibid., p. 23.

${ }^{4}$ Ibid., p. 18.

5Ibid., p. 32.
}

142 || Volume 27, Nomor 2, Oktober 2017

AL-AHKAM p-ISSN: 0854-4603; e-ISSN: 2502-3209 
the answer to the comprehensive question. In brief, it is the comprehensive answer that someone can find for himself what it means to be an authentic human being. Because religious conviction provides the authenticity of human beings, it is not wise to expel religion from the political arena. But, as a consequence, the religious conviction has to be ready to enter into a free and public debate. Thus, in democratic discourse, attempting to make religious teaching to be a state policy is politically acceptable. But, before a given religious teaching becomes a state policy, it must be debated publicly to determine its validity. By referring to human experience and reason, the validity of a given religious teaching can, of course, be tested in public debate. ${ }^{6}$

While Prof. Gamwell suggests that religion is important to politics ${ }^{7}$, Prof Rawls believes the contrary. Rawls ${ }^{8}$ suggests that political conceptions must be based on "justice as a free-standing view". But, the "free-standing view" is impossible to be manifested in political conceptions without a fair system of cooperation ${ }^{9}$ and toleration. ${ }^{10}$ In order to be fair, the concept of justice should be purged from religious and metaphysical doctrine, except what is "implied by the political conception itself".11 He calls such a concept of justice "justice as a fairness". Thus, for Rawls, no religious convictions or religious traditions in the community are important to politics. This can be inferred from his conception of justice. A political conception must be independent of wider doctrines, either religious or secular ethical doctrines.

Rawls believes that human beings have a capacity to create "a fair system of cooperation over time". ${ }^{12}$ Why? Because they have "two moral powers", namely a capacity for a sense of justice, that is, the capacity to honor fair terms of what is considered as good..$^{13}$ Thus, according to Rawls, a reasonable person

\footnotetext{
6Ibid., p. 190.

${ }^{7}$ Nor Hasan, “Agama dan Kekuasaan Politik Negara”, Jurnal Karsa, Vol. 22, No. 2, December 2014. 8John Rawls, Political Liberalism (New York: Columbia University Press, 1993), p. 11.

9 John Rawls, Political Liberalism, p. 23. John Rawls, Justice as Fairness, A Restatement (Cambridge: Harvard University Press, 2001), p. 5.

10John Rawls, Political Liberalism, p. 10.

11 Ibid., p. 10.

12 Ibid., p. 14.

13Ibid., p. 19.
} 
Abu Hapsin

must be able to concept principles of justice as fairness even though they differ in their religious backgrounds.

From the above explanation, it is clear that "justice as fairness" requires religion to be left behind when we enter the political arena. We have to come to the political arena with our "original position". This means that we have to put off whatever attributes we possess, either these related to our religious convictions, ideologies or social organizations. Thus, we come to the political arena only as a citizen, not as a Muslim, a Christian, a Buddhist, neither as an atheist. For Rawls, this is important for the sake of fulfilling a fair agreement and fair cooperation among the body politic. ${ }^{14}$ Religious teachings cannot be made as a reference in public debate. This what makes Gamwell ${ }^{15}$ accuses "privatises" like John Rawls of having treated religious beliefs as irrational, and, hence it cannot be the subject of public debate. It is solely a matter of faith and confession. For Gamwell, because the authenticity of human beings can only be found in their freedom to choose what has been their conviction, referring to a given religious conviction in the political arena is justifiable. But, consequently, religion must be ready to be debated publicly.

The full and free debate is only possible if we change our perspective from the thesis of religion as non-rational to the thesis of religion as rational. This is the first and foremost step to be taken into consideration if we would like to follow Gamwell's ideas about overcoming the political problems related to religious freedom. It is a necessary condition for following the step proposed by him, namely a "democratic resolution". Thus, before we come to the political arena, our minds should agree upon the idea that religious convictions or religious teachings are subject to public debate and discussion. Muslims, for example, cannot merely say that because implementing Islamic Law is the obligation dictated by God in the Qur'an, there is no other choice but that the state must implement it. This is not a rational argument in the eyes of democracy, even though it might seem reasonable to Muslims. Such a position, however, would eliminate the function of full and free debate. This is why very religious adherent is free to refer to his comprehensive understanding or

${ }^{14}$ Ibid., p. 22-23.

15Franklin I Gamwell, The Meaning of Religious Freedom, p. 4. 
religious teaching in the political debate. Muslims are allowed to refer to their Shari'a, similarly, Christians are allowed to refer to their canonical book as a reference, Buddhists are justifiable to base their arguments on Tri Pitaka and atheist groups can use their personal truth to buttress their arguments. In brief, every religious adherent is free to use his or her religious teachings as a reference or as a basis for political debate. This is different from the idea of justice as a free-standing view of John Rawls which requires justification only from the ideas that are implicit in the political culture. ${ }^{16}$ Hence, no religious conviction is important to politics. Religious conviction should be left behind when we play in the political arena.

The Democratic resolution of religious freedom entails a democratic constitution. A democratic constitution should encompass and answer both the political as well as religiously formulated problems. The formulation of a political problem would ask: is a given constitution consistent with a plurality of legitimate religions, while the formulation of a religious problem would ask: can a given constitution be affirmed by adherents of a plurality of religions ${ }^{17}$. These two problematic formulations are of great significance for determining whether the public view or public debate can be worked out. A given constitution that does not encompass the answer to these two problematic formulations is not a democratic constitution.

Now, let us examine the UUD 45 to see whether or not it is consistent with a legitimate plurality of religion. Article 29 verse (1) UUD 45 says "The state shall be based upon belief in One, Supreme God". The formal interpretation of this article does not give any kind of definition as to what the definition of religion is and how many religions are considered as legitimate. But referring to the fact that there are only six religious traditions which are represented by the Department of Religious Affairs of the Republic of Indonesia, namely Confucianism, Buddhism, Hinduism, Catholicism, Protestantism, and Islam, indicates that only religions which have systems of belief in the oneness of ultimate reality are considered as legitimate. Thus, there is a reduction in meaning concerning religious freedom. To be fully authentic, human beings

16John Rawls, Political Liberalism, p. 10.

17Franklin I Gamwell, The Meaning of Religious Freedom, p. 161. 
should, of course, be free to choose whatever they believe. If his conscience believes in the absence of God, let him be an atheist.

A democratic constitution must also identify the participants in the discussion or debate and their rights in order that the discussion can be fully free. A procedure for making and executing decisions must also be included in the constitution. In order to maintain the condition for a fully free debate, the constitution itself must be subject to continual assessment. Thus, a procedure for changing or amending the constitution must be explicitly stated in the constitution. All of these constitutional procedures must first be affirmed by all political communities ${ }^{18}$. In other words, a democratic constitution should reflect the affirmations of all religious adherents. This affirmation is of great importance because such constitutional procedures are those decisions made prior to all later state policies and rules, and to which they must be referred.

If these requirements have been fulfilled, logically it would be impossible for a state to give some support to any one religious tradition or religious teaching, for instance, if because the majority of the population of a given state is Muslim its constitution should state "Islam is the state religion". Meanwhile, another of its clauses states "The state shall guarantee to every citizen adherence to his/her own religious teaching". These two clauses, even though they look convincing and just, according to the democratic discourse are void. Why? Because the explicit support of the state to a given religion will automatically eliminate the right of other religious adherents to have a free and full debate in the political arena. These clauses are inconsistent with existing legitimate religious convictions. A democratic constitution must be neutral in any explicit claim of any "comprehensive" understanding. This is what has been the character of the Indonesian Constitution, the UUD 45.

The democratic decision produced by a democratic constitution might not satisfy some religious adherents. But insofar as the procedure reflects justice, in the sense that procedure has been stipulated through agreement before the decision emerges, there is no reason for other religious adherents not to obey that decision. In other words, they might be in disagreement with that decision, but they have to

18Ibid., p. 163. 
obey and respect as long as it is stipulated through an agreed procedure. Inconsistency to the democratic procedure means inconsistency to the preceding commitment and inconsistency to the idea of religious freedom itself.

The feeling or the stance that a given constitution is just might change from time to time. A given religious adherent might feel that the decision-making procedure written explicitly in the constitution is just and, therefore, they are bound to a commitment to it. But, later, after undertaking a series of debates, they find the decision-making procedure unjust. As a result, they want to change their previous commitment.

Democratic discourse, however, does not regard changing commitment as an aberration of the commitment itself. Changing commitment to the overriding decisions, namely the decision-making procedures written in the constitution, is justifiable. Those who disagree must have room in the constitution in order to persuade other religious adherents, that a certain decision-making procedure written in the constitution must be changed. While they have the opportunity to persuade the other religious adherents to change their commitment to the overriding decisions, at the same time they have to respect and comply with the decisions produced through that decision-making procedure with which they now disagree. ${ }^{19}$

With the above description, it is understandable that there is a distinction between formal and material claims about justice. Formal justice is a justice which is reflected by, and manifested in, the constitutional procedure that overrides other later decisions. As long as the overriding constitutional procedure has been affirmed by the other religious adherents, there has been a claim about justice. Thus, the affirmation of the other religious adherents to the overriding constitutional procedure is a decisive factor in determining that the formal claim about justice has been fulfilled, while material justice is a justice manifested in the decision produced later through the constitutional procedure.

In democratic discourse, what has been at stake is the formal claim about justice. The material claim about justice might be different from one or another adherent of various religious traditions. But as long as the formal claim about justice manifested in the procedure of making, executing, enforcing and

19 Ibid., p. 167. 
changing decisions is affirmed by the adherents of all religious convictions democratic discourse can work out. Thus, even though the material claim about justice manifested in a given ordinance cannot satisfy all religious adherents, they must obey that ordinance since it is stipulated through the overriding constitutional procedure that has fulfilled the criteria of the formal claim of justice.

Although a democratic constitution emphasized the importance of procedural justice of the formal claim about justice, this does not mean that material justice can be neglected. The material claim abuts justice manifested in a given ordinance stipulated through a just and constitutional procedure must also be tested and validated by appealing to human experience and reason ${ }^{20}$. For instance, Indonesian parliament stipulated an ordinance allowing the practice of slavery. The ordinance is, finally, stipulated through polling after having been debated freely and in accord with the affirmed and just constitutional procedure. Although this ordinance is stipulated through the procedural justice and is passed through democratic principles, it is not in line with the idea of democratic discourse since human reason and experience regard practicing slavery as morally inhumane. Thus, there is a room for moral appraisal. ${ }^{21}$

Given the above explanation, I would like to demonstrate that UUD 45 follows the principles of procedural justice and, hence it is a democratic constitution. Its position is neutral in relation to existing religions in Indonesia. None of them is given special treatment. All religious adherents have an equal position in law and government, and they have the equal right to work and to have a better living (article 27). Every citizen, without regard to religious background, has the right to freedom of association and assembly, they have the right to express their thought and publish them (article 28), and they have the right to obtain an education. The UUD 45 is also subject to continual assessment. It can be changed provided that two-thirds of the member of the

\footnotetext{
${ }^{20} \mathrm{Ibid}$, p. 190.

21It is not the right place here to discuss whether a moral judgment is philosophically sound or not. David Lyons has elaborated in length about this matter. For further inquiry see (David Lyons , Ethic and The Rule of Law (Cambridge: Cambridge University Press, 1993), p. 1-35. See. Zaenal Arifin Hoesein, "Pembentukan Hukum dalam Perspektif Pembaruan Hukum", Jurnal Recht Vinding, Vol. 1, No. 3, Desember 2012, p. 308.
} 
MPR (The people's consultative body) agree. In brief, the UUD 45 has fulfilled the provisions maintained as establishing a just procedural constitution.

Based on the UUD 45, none of the existing religions in Indonesia has a privileged place. Islam is not the state religions and, therefore, the position of Islamic law is the same as that of other religious teachings. Thus there is a wide room given for Islamic law, and for the other religious teachings as well, to become a state policy, Islamic law can no longer be claimed "explicitly" as Islamic law, because it is not providing now an answer to the comprehensive question, but only to the partial question, namely the question of how to administer the state. Its function in the society has changed from answering "explicitly" the comprehensive questions to answering "explicitly" the question about the state's legal policy.

\section{Making Islamic Law as Social Norms}

A social norm is a form of "behavioral regularities" whose function is a nonlegal mechanism of social cooperation, ${ }^{22}$ Posner believed this behavioral regularities result from the interactions of the individual acting in their rational self-interest that drives peoples to cooperate across all areas of life..$^{23}$ The difference between social norms and other behavioral regularities lies in their consequences. Departure from the social norms provokes sanctions. But the sanction emerges endogenously as a consequence of people acting in their rational self-interest. ${ }^{24}$ Stigmatization of the deviant and ostracism of the incorrigible is the sanction which is commonly imposed on those who break the agreement of social norms. ${ }^{25}$

The above feature looks very Hobbesian. For Thomas Hobbes, as quoted by Kamenka ${ }^{26}$, the state of nature of humans beings is nasty and brutish. This is why humans beings need government and a code of law as a form of their social contract. Thus, it is self-interest alone that drives people to cooperate across all areas of life, including creating government and law.

\footnotetext{
22Eric A. Posner, Law and Social Norms (Cambridge: Harvard University Press, 2000), p. 4.

${ }^{23}$ Ibid., p. 7.

${ }^{24}$ Ibid., p. 8.

25 Ibid., p. 3.

${ }^{26}$ Eugene Kamenka, "Community, and The Socialist Ideal," in Eugene Kamenka, (ed.) The Community as a Social Ideals (London: Edward Arnold Ltd.., 1982), p. 3.
} 
Abu Hapsin

Without regard to the defect found in Posner's statement, for self-interest is not the only things that motivated and united people to cooperate together, what I would like to highlights is that behavioral regularities that serve as a non-legal mechanism of social cooperation exist in society. Thus, the function of law as a mechanism of social integration is merely complementary. Without law or legal rule, actually, the social norms have been able to unite every member of the society in togetherness. Thus, social norms are like a "social contract" whose bindingness depends fully on the readiness of the society to accept that contract. As long as the society is still in agreement to accept that contract, they would be loyal to it. The absence of loyalty and obedience is usually signaled by the emergence of deviant behaviors or of social protest. However, the emergencies of deviant behaviors or social protest are not the primary subject of the moral appraisal. In other words, a person who deviates from the social norms can not be judged morally as right or wrong, for if all members of society practice cohabitation, for example, one who does not will be considered as deviant, or, if all member of a society justify slavery, one who condemn it will be considered deviant. Thus, the primary subject in the moral appraisal is the norm that unites individual in society, not a deviant behavior, by referring to human reason and experience, social norms or behavioral regularities that unite people to cooperate together might be evil norms, but people continue to cooperate together on the basis of that norms.

From the above feature, it is clear that the loyalty of the people to maintain their social norms is not because of extraneous factors, but it is more motivated by endogenous factors. With the existing social norms, every member of the society will regard that deviant behavior as a stigma that can ruin a person's reputation within that society. This is the endogenous power of social norms that will lead to the togetherness of the society. This is why the legislation of a given norms which has been accepted by society as their social norm would be effective. As stated above, in such a condition the function of law with respect to the maintenance of the regularities of social behavior is complimentary in nature. In other words, the function of law here is only to preserve the status quo.

The function of law in a society can be classified into two kinds, namely law as a form of social control and law as social engineering. As a social control, the 
law is intended to preserve the order as well as the existing pattern of life of the society. Law is directed to maintain the social system by forcing every member of that society to comply with the social system they have established. Thus the social system is like a "contract" of all the members of the society. Whoever breaks the contract, he/she is liable to have a punishment ${ }^{27}$. While law as social control looks more static and is intended to preserve the status quo, law as social engineering is more dynamic. Law is not merely directed to maintain the existing social system but it is also directed to lead the society to certain objectives. In this respect, the law function as a mechanism to create a new social system ${ }^{28}$ and hence, the law is educative and can be used as a tool of the vehicle for social change. Here is where social change becomes possible. The present social norms might not reflect the underlying values of a democratic society. In such a situation, the new law might educate people into new behavioral regularities. But at the same time, education about this underlying values must be done to persuade the people to adopt new patterns and new moral sentiment.

Because another function of law is a mechanism to guarantee what has become a "social contract", consequently the law should be built on the basis of social norms. The law that s not based on the social norms will not produce social awareness to abide by that law. The awareness to abide by the law is of a great significance for the sake of a legal effectiveness or enforceability.

It is right, however, that the effectiveness of a given legal rule is not fully determined by the acceptance of the society of the norms upon which the legal rule is built. The effectiveness of a legal rule is also determined by the institution of law enforcement, such as the police, persecutors, judges and the judicial system. However, a legal rule which is not based on living norms will lead to strong resistance from the society. If this happens, the legal rule is nothing other than a "dead norm".

With political power, a certain norm might be legislated to be a state policy for the sake of directing social change. In such a condition, the law does not only reflect social norms but also serve as a pattern to mold another social

\footnotetext{
27Satjipto Rahardjo, Pemanfaatan Ilmu-ilmu Sosial bagi Pengembangan Ilmu Hukum (Bandung: Penerbit Alumni, 1977), p. 145.

$28 \mathrm{Ibid}$.
} 
norm. For instance, the Islamic law concerning adultery and fornication, with political power, might be legislated to become a part of Indonesian criminal law. But if the society is not ready to accept the law, social disobedience might happen. Law that is not rooted in the norm prevailing in the society will not gain support from the society. In order for the law to be effective, support from the society is a necessary condition. This is why law reformation is nothing other than an effort directed to reorient and reevaluate the socio-cultural values underlying the existing legal rules ${ }^{29}$. This, of course, must be the main and the first step should be taken into consideration by every religious community, including Muslims in Indonesia, before reforming the existing law.

That Islam is the religion of the majority of Indonesia is not questionable. But the question as to the whether their adherence to Islam informs their religious commitment as required by Islam is left unanswered. It is for this reason many religious communities have tried to think realistically. Nahdlatul Ulama (NU), Muhammadiyah and MUI, for instance, think that Indonesia with Pancasila as its ideology is a final form of the state.

For those who think realistically, making Islamic law formally as positive law is unrealistic, for Indonesia is a state with pluralistic society, either seen from religious conviction, ethnicity, race or cultural traditions. This diversity could be considered as a positive national resource in one side, but on the other side, it could also lead to a national disintegration. This condition is worsened by the fact that the spread of a given religious group is concentrated on a certain island. For instance, Hinduism in Bali, Catholic in Flores, Protestant in West Papua, Islam in Java and Sumatra etc. thus Indonesia is actually a "fragile" country. This is why the government and the whole element of society, especially religious leaders, have to work together so that pluralism and diversity could be managed in a proper way.

Aware of the fact that ideologically Indonesia is not religiously based state, effort should be focused on upholding Islamic law in cultural level, not in supra-political structure. For Muslim who think realistically, spreading Islamic law in order to become living tradition is more important than attempting to

\footnotetext{
${ }^{29}$ Barda Nawawi Arief, Bunga Rampai Kebijakan Hukum Pidana (Bandung: PT. Citra Aditya, 1996), p. 32.

152 || Volume 27, Nomor 2, Oktober 2017

AL-AHKAM

p-ISSN: 0854-4603; e-ISSN: 2502-3209
} 
formalize it to be the state law. This idea is in line with concept proposed by al'Alim, A. Sahal Mahfudh, a chair person of the consultative body of NU. In his very popular book (at least in Indonesia) "Fiqh Social" he proposed that fiqh social is not intended to formalize Islamic law (fiqh) as a state legal policy in a formal way, but it is intended to make fiqh as a social norm. ${ }^{30}$

Based on the above feature, to avoid the clash with the other groups of religious convictions, creating a religious cultural environment in a society is more important than formalizing Islamic law to be the state legal policy. Presenting a substantial aspect of Islamic law or Islamic teachings is far more meaningful for the sake of manifesting individual as well as society piety, rather than presenting symbols or forms. In religious life, symbols are of course important, without which Islam will be reduced into individual faith. However, if we deal with only two options, symbols or forms and substance, our choice is certainly the second one, namely the substance. In the context of Indonesian political as well cultural life, this choice is the most realistic one.

\section{Concluding Remarks}

From the above discussion, it can be concluded that religious teachings such as Islamic Law can become Indonesian legal policy provided that is supported constitutionally and accepted sociologically.

Constitutionally speaking, Indonesian Constitution (UUD 45) gives freedom to every follower of a given religion to concretize his religious convictions in public life provided that, in doing so, the fundamental right of others are not offended. The UUD 45 also gives freedom to every citizen to make his religious convictions or religious teachings become a state legal policy as long as he or she follows the procedural constitution written in the UUD 45. However, after becoming state legal policy, Islamic law can no longer be claimed "Islamic Law", because its now provided for answering the partial question of life, namely how to administer the state.

From a sociological point of view, in order that the process of legislation runs smoothly, Islamic Law should first be transformed into living norms.

\footnotetext{
30Munawar Aziz, "The Concept of Civilization on Islam Nusantara”, Jurnal Lektur Keagamaan, Vol. 13, No. 2, 2015.
} 
Abu Hapsin

Hence, it will be easier for the society to abide the law which originated from living norms. Since the function of law in maintaining public peace and order depends, for its effectiveness, on the actual social norms of the community, social acceptance is of great importance.[a]

\section{BIBLIOGRAPHY}

Arief, Barda Nawawi, Bunga Rampai Kebijakan Hukum Pidana, Bandung: PT. Citra Aditya, 1996.

Attabani, G. Salahuddin, "Islamic Shari'a and The Status of Non-Muslim", in Tarek Mitri, (ed.) Religion, Law and Society, Geneva: World Council of Churches, 1995.

Audi, Robert, and Wolterstorff, Nicholas, Religion in The Public Square, The Place of The Religious Conviction in Political Debate, Boulder: Rowman \& Little Filed Publisher Inc, 1997.

Aziz, Munawar, "The Concept of Civilization on Islam Nusantara”, Jurnal Lektur Keagamaan, Vol. 13, No. 2, 2015.

Bassiouni, M. Cherif, (ed.), The Islamic Criminal Justice System, New York: Oceana Publications, Inc., 1982.

Devlin, Patrick, The Enforcement of Morals, New York: Oxford University Press, 1977.

Gamwell, Franklin I, The Meaning of Religious Freedom, Modern Politic and The Democratic Resolution, Albany: State University of New York Press, 1995.

Greenawalt, Kent, Religious Conviction and Political Choice, New York: Oxford University Press, 1988.

Hart, H.L.A., Law, Liberty, and Morality, Oxford: Oxford University Press, 1963.

Hasan, Nor, “Agama dan Kekuasaan Politik Negara”, Jurnal Karsa, Vol 22, No. 2, Desember 2014.

Hefner, Robert M. and Horvatich, Patricia, Islam di Era Negara Bangsa (Islam in The Era of Nation State), (trans. Imron Rosyidi), Yogyakarta: Tiara Wacana, 2001.

Hoesein, Zaenal Arifin, "Pembentukan Hukum dalam Perspektif Pembaruan Hukum", Jurnal Recht Vinding, Vol 1, No. 3, Desember 2012 
Kamenka, Eugene, "Community, and The Socialist Ideal", in Eugene Kamenka, (ed.), The Community as a Social Ideals, London: Edward Arnold Ltd. 1982.

Koshy, Ninan, Religious Freedom in a Changing World, Geneva: World Council of Churches Publication, 1992.

Lee, Keekok, The Positive Science of Law, Hampshire, England: Gower Publishing Group, 1989.

Lyons, David, Ethic and The Rule of Law, Cambridge: Cambridge University Press, 1993.

Peczenik, Aleksander, On Law and Reason, Dordrecht: Springer Science and Business Media, 1989.

Rahardjo, Satjipto, Ilmu Hukum, Bandung: PT Citra Aditya Bakti, 1996.

Pemanfaatan Ilmu-ilmu Sosial bagi Pengembangan Ilmu Hukum, Bandung: Penerbit Alumni, 1977.

Rauf, Muhammad Abdul, Tan Sri., The Concept of Islamic State; With Particular Reference to Treatment of Non-Muslim Citizens, Malaysia: Islamic Affairs Division Prime Minister's Departement, 1998.

Rawls, John, Political Liberalism, New York: Columbia University Press, 1993. Theory of Justice, Cambridge: Harvard University Press, 1971. Justice as Fairness, A Restatement, Cambridge: Harvard University Press, 2001.

Rosen, Lawrence, The Justice of Islam, Comparative Perspective on Islamic Law and Society, New York: Oxford University Press, 2000.

Unger, Roberto Mangabeira, Law in Modern Society, Toward a Criticism of Social Theory, London: The Free Press (MacMillan Publishing Co.), 1976.

The Critical Legal Studies, London: The Free Press (MacMillan Publishing Co.), 1983.

Zahra, Muhammad Abu, Ușūl al-Fiqh, Cairo: Dār al-Fikr al-Arabi, n.d. 
156 || Volume 27, Nomor 2, Oktober 2017 